\title{
PENERAPAN PEMBELAJARAN MODEL COOPERATIVE INTEGRATED READING AND COMPOSITION (CIRC) BERBANTUAN WEBSITE BLOGSPOT PADA MATA KULIAH METODOLOGI PENELITIAN PENDIDIKAN FISIKA
}

\author{
Sri Fatmawati \\ IAIN Palangka Raya \\ e-mail: sri.fatmawati@iain-palangkaraya.ac.id
}

\begin{abstract}
Abstrak
Penelitian ini bertujuan menerapkan Pembelajaran CIRC Berbantuan Website Blogspot pada mata kuliah metodologi penelitian pendidikan fisika. Metode penelitian ini menggunakan metode pre-experiment dengan one group pre-test post-test design. Hasil Penelitian menunjukkan peningkatan hasil belajar mahasiswa setelah Pembelajaran CIRC Berbantuan Website Blogspot yaitu rata-rata pre-test 14,00, rata-rata post-test 67,44 dan rata-rata $\mathrm{N}$-Gain 0,62 , kategori sedang. Uji perbedaan rata-rata hasil belajar mahasiswa sebelum dan setelah Pembelajaran CIRC Berbantuan Website Blogspot dapat disimpulkan bahwa terdapat perbedaan yang signifikan nilai pre-test dan post-test pada penerapan Penerapan Pembelajaran CIRC Berbantuan Website Blogspot.
\end{abstract}

Kata Kunci: hasil belajar,CIRC, metodologi penelitian pendidikan fisika

\begin{abstract}
This study aims to apply CIRC Learning Assisted by Blogspot Website in the subject of physics education research methodology. The method of the study used the preexperiment and research design method was one group pre-test post-test design. Research Results show an increase in student learning outcomes after CIRC Learning Assisted Blogspot website that is the average pre-test 14.00, post-test average 67.44 and $\mathrm{N}$-Gain average 0.62 , medium category. Test the difference in average student learning outcomes before and after CIRC Learning Assisted Blogspot Website can be concluded that there is significant differences in the value of the pre-test and post-test on the application of CIRC Learning Implementation Assisted by Blogspot website.
\end{abstract}

Keywords: learning outcomes, CIRC, research methodology of physics

\section{PENDAHULUAN}

Mata Kuliah Metodologi Penelitian Pendidikan Fisika merupakan salah satu mata kuliah keahlian yang ada di Program Studi Tadris Fisika. Capaian pembelajaran Mata kuliah ini terdiri dari capaian pembelajaran pengetahuan dan keterampilan kerja. Capaian pengetahuan adalah mahasiswa mampu menguasai metode penelitian pendidikan fisika. Capaian keterampilan kerja adalah mahasiswa mampu melakukan penelitian pendidikan fisika dalam bentuk pengkajian dan evaluasi pembelajaran fisika dengan pendekatan kuantitatif dan/atau kualitatif untuk memecahkan permasalahan pembelajaran fisika dan dilaporkan dalam bentuk artikel ilmiah. Tujuan akhir dari mata kuliah ini tidak hanya pada 
pemahaman tentang metode penelitian tetapi juga mahasiswa mampu menghasilkan rencana proposal penelitian sebagai salah satu syarat dalam menyelesaikan tugas akhir.

Kesulitan yang terjadi pada mahasiswa yang mengambil mata kuliah metodologi penelitian adalah masih lemah dalam merumuskan permasalahan penelitian yang dikaji. Mahasiswa masih belum terbiasa menganalisis artikel hasil penelitian sebagai rujukan penelitian. Mahasiswa belum bisa menyusun proposal penelitian dengan baik. Hal ini dimungkinkan masih lemahnya pemahaman tentang konsep metodologi penelitian.

Pembelajaran CIRC menugaskan setiap mahasiswa bertanggungjawab terhadap tugas kelompok. Setiap anggota kelompok saling mengeluarkan ide-ide untuk memahami suatu konsep dan menyelesaikan tugas, sehingga terbentuk pemahaman dan pengalaman belajar yang lama (Huda, 2013) . Hal ini sejalan dengan pendapat Madhu Gupta dan Jyoti Ahuja (2014) yaitu tugas membaca secara berkelompok akan memberikan kesempatan kepada seluruh anggota berdiskusi tentang suatu topik dan dapat saling membantu memecahkan suatu permasalah yang ditemukan bersama.

Penelitian yang dilakukan oleh Putranto (2010) menjelaskan bahwa kelebihan dari model CIRC adalah siswa dapat memberikan tanggapannya secara bebas, dilatih untuk dapat bekerjasama dan menghargai pendapat orang lain. Kekurangan dari model CIRC yaitu pada saat presentasi hanya siswa yang aktif tampil memerlukan waktu yang relatif lama, adanya kegiatan-kegiatan kelompok yang tidak bisa berjalan seperti apa yang diharapkan.

Perkembangan ilmu pengetahuan dan teknologi mampu merubah perilaku kehidupan mahasiswa salah satunya adalah dalam proses belajar. Mahasiswa mendapatkan informasi dengan mudah melalui akses internet yang sangat terbuka. Pembelajaran berbantuan e-learning merupakan hal yang perlu dilakukan sebagai seorang fasilitator pembelajaran, sehingga mahasiswa dapat memanfaatkan akses internet untuk hal yang bermanfaat.

Pembelajaran dengan e-learning merupakan pembelajaran dengan memanfaatkan teknologi internet untuk meningkatkan lingkungan belajar dengan konten yang kaya dengan cakupan yang luas (Hanum, 2013; Kusmana, A. 2017). E-learning merupakan pemanfaatan media pembelajaran menggunakan internet, untuk mengirimkan serangkaian solusi yang dapat meningkatkan pengetahuan dan keterampilan (Marwah dan Kustijono, 2013:). Website blogspot adalah salah satu fasilitas dari internet yang dapat digunakan sebagai media pembelajaran. Blogspot adalah halaman web pribadi yang ditulis secara berurutan dan dikelola melalui perangkat lunak tertentu. Hasil penelitian oleh Juniawan at al., (2017) tentang media pembelajaran berbantuan ICT berupa website blogspot pada pembelajaran fisika menunjukan hasil dapat meningkatkan hasil belajar siswa. 
Pembelajaran pada matakuliah metodologi penelitian fisika masih menerapkan metode diskusi dan memanfaatkan media power point. Dosen menjelaskan materi dan selanjutnya mendiskusikan dengan mahasiswa. Dosen memberikan contoh-contoh artikel penelitian dan mendiskusikannya bersama mahasiswa. Pembelajaran masih dominan kepada dosen. Diskusi kelompok pernah diterapkan walaupun masih belum mendominasi pembelajaran. Dosen belum pernah mencoba menerapkan pembelajaran yang berbantuan website blogspot. Metode yang sudah digunakan tersebut cukup mempengaruhi hasil belajar mahasiswa. Mahasiswa masih lemah dalam hal kreativitas dalam menyusun topik penelitian, cenderung monoton dan kurang bervariasi.

Pembelajaran metodologi penelitian fisika berbantuan website blogspot diharapkan mampu mengembangkan pemahaman mahasiswa dalam konsep metodologi penelitian, menambah wawasan mahasiswa. Mahasiswa juga ikut terlibat aktif dalam proses pembelajaran. Mahasiswa diharapkan dapat mengenal jurnal-jurnal hasil penelitian yang akan mendukung mereka dalam merancang rencana proposal penelitian sebagai tugas akhir, sehingga dengan upaya ini mampu mempercepat masa studi mahasiswa di Prodi Tadris Fisika yang selama ini masih diatas rata-rata 5 tahun yang mana salah satu penyebabnya adalah belum menemukan permasalahan yang akan diangkat menjadi topik penelitian dan masih belum memahami bagaimana merancang proposal penelitian yang baik.

\section{METODE}

Metode dari penelitian ini menggunakan metode pre-experiment, dengan desain penelitian yang digunakan adalah one group pretest-postest design.Penelitian dilaksanakan Program Studi Tadris Fisika FTIK IAIN Palangka Raya pada bulan Maret November Tahun 2017. Populasi pada penelitian ini adalah seluruh mahasiswa semester V pada Program Studi Tadris Fisika yang mengambil mata kuliah Metodologi Penelitian Fisika. Sampel diambil menggunakan total sampling karena jumlah populasi sama dengan jumlah sampel. Jumlah sampel mahasiswa adalah 09 (Sembilan) orang mahasiswa yang memprogramkan mata kuliah metodologi penelitian fisika.

Teknik pengumpulan data yang digunakan dalam penelitian ini antara lain tes. Kuliah Metodologi Penelitian Fisika. Instrumen yang digunakan adalah tes hasil belajar. Instrumen ini divalidasi oleh teman sejawat/Dosen.

$\mathrm{N}$-gain digunakan untuk mengetahui peningkatan hasil belajar mahasiswa. $\mathrm{N}$-gain masingmasing kelas digunakan rumus sebagai berikut (Hake, 1998:64-74) :

$$
<\mathrm{g}>=\frac{\text { skor tes akhirg } 6 \text {-skor awal\% }}{100-\text { skor tes awal\% }}
$$


Tabel 1. Kriteria Indeks N-Gain

\begin{tabular}{cc}
\hline Indeks N-Gain & Interpretasi \\
\hline$<\mathrm{g}>>0,70$ & Tinggi \\
$0,30<<\mathrm{g}>\leq 0,70$ & Sedang \\
$<\mathrm{g}>\leq 0,30$ & Rendah \\
\hline
\end{tabular}

Pengujian hipotesis perbedaan signifikansi pengaruh pembelajaran setelah diterapkan Pembelajaran CIRC berbantuan Website Blogspot terhadap hasil belajar mahasiswa dilakukan menggunakan SPSS for Windows 17.0 Kriteria pada uji ini apabila hasil uji Paired Sample T Test lebih kecil dari nilai alpha/taraf sigifikansi 0,05 maka terdapat perbedaan yang signifikan antara tes awal dan tes akhir.

\section{HASIL DAN PEMBAHASAN}

Tes dilakukan sebelum pembelajaran (pre-test) dan sesudah pembelajaran (posttest) menerapkan model pembelajaran CIRC Berbantuan website Blogspot. Data hasil pretest, post-test, gain, dan $\mathrm{N}$-gain dapat dilihat pada tabel 2 yaitu rata-rata pre-test adalah 14,00 , rata-rata pos-test 67,44 adalah dan rata-rata N-Gain adalah 0,62 .

Tabel 1. Data Hasil Pretest, Posttest, dan N-gain

\begin{tabular}{ccccc}
\hline Mahasiswa & Pre-test & Post-test & N-Gain & Kategori \\
\hline RP & 23 & 68 & 0,58 & Sedang \\
SP & 18 & 74 & 0,68 & Sedang \\
MS & 10 & 53 & 0,48 & Sedang \\
LC & 18 & 73 & 0,67 & Sedang \\
SS & 10 & 78 & 0,76 & Tinggi \\
AM & 7 & 68 & 0,66 & Sedang \\
EP & 10 & 75 & 0,72 & Tinggi \\
UK & 6 & 45 & 0,41 & Sedang \\
RA & 24 & 73 & 0,64 & Sedang \\
\hline Rata-rata & 14,00 & 67,44 & 0,62 & Sedang \\
\hline
\end{tabular}

Gambar 1. Menunjukan persentase rata-rata tingkat N-gain Mahasiswa setelah pembelajaran menggunakan model CIRC Berbantuan website Blogspot. Persentase mahasiswa yang peningkatannya termasuk dalam kategori rendah adalah $0 \%$, kategori sedang adalah $77,78 \%$ dan kategori tinggi adalah $22,22 \%$. 


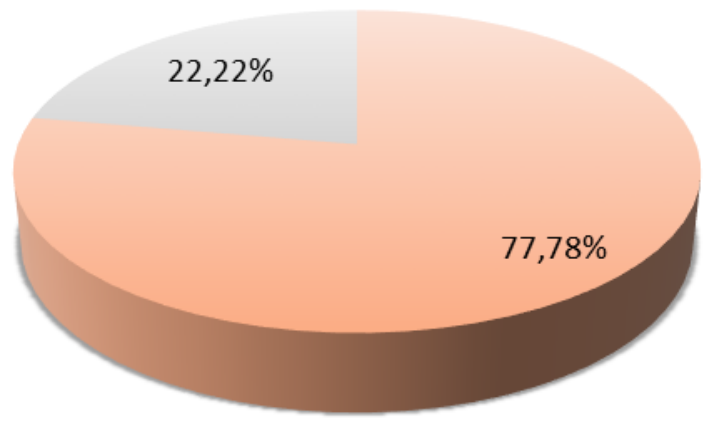

$\bowtie$ RENDAH $₫$ SEDANG $\backsim$ TINGGI

Gambar 1. Persentase Rata-Rata Tingkat N-gain

Uji hipotesis perbedaan rata-rata hasil belajar antara sebelum dan setelah pembelajaran menggunakan model pembelajaran CIRC berbantuan website blogspot menggunakan uji statistik parametrik yakni uji dependent-samples t test. Uji ini untuk data yang diasumsikan berdistribusi normal dan homogen, dengan kriteria pengujian apabila nilai signifikansi > 0,05 maka Ho diterima dan Ha ditolak, sedangkan jika signifikansi < 0,05 maka Ha diterima dan Ho ditolak.

Tabel 2. Uji Beda Hasil Akhir

\begin{tabular}{crcrccc}
\hline Hasil Belajar & N & Rata-rata & SD & Uji & Sig $^{*}$ & Keterangan \\
\hline Pre-test & 9 & 14.00 & 6.83 & Paired & \multirow{2}{*}{0,00} & Ada perbedaan \\
Post-test & 9 & 67.44 & 11.10 & Samples & & yang signifikan \\
\hline
\end{tabular}

Tabel 2 menunjukkan bahwa terdapat perbedaan yang signifikan sebelum dan setelah pembelajaran CIRC berbantuan website blogspot. Mahasiswa secara aktif dalam pembelajaran menggunakan model CIRC berbantuan website blogspot selama proses pembelajaran. Hal ini memberikan dampak pada hasil belajar mahasiswa. Rata-rata peningkatan hasil belajar Mahasiswa meningkat sebelum dan setelah pembelajaran dengan kategori N-Gain sedang yaitu 0, 62. Sebelum kegiatan pembelajaran rata-rata mahasiswa masing belum memahami dengan baik tentang pengertian Metode Penelitian Pendidikan, jenis-jenis metode penelitian, karakteristik metode kuantitatif dan kualilatif, rumusan masalah penelitian fisika/pendidikan fisika, variabel dalam penelitian. Rata-rata pretest mahasiswa hanya sebesar 14,00 dari skor maksimum 100 dan setelah pembelajaran rata-rata skor post-test mahasiswa adalah 64,44.

Kegiatan membaca dan menulis secara bersama yang dilakukan mahasiswa baik pada saat tatap muka dan on-line memberikan pengaruh terhadap pemahaman 
mahasiswa. Mahasiswa dalam kegiatan pembelajaran membaca dan menulis secara bersama anggota kelompok menemukan sendiri konsep tentang pengertian metode penelitian pendidikan, jenis-jenis metode penelitian, karakteristik metode kuantitatif dan kualilatif, rumusan masalah penelitian fisika/pendidikan fisika dan variabel dalam penelitian. Dosen bertugas memfasilitasi dengan mempersiapkan bahan bacaan berupa artikel dan materi dari buku metodologi penelitian. Dosen memberikan penuntun melalui Lembar Kerja Mahasiswa (LKM).

Tugas mahasiswa pada LKM I adalah masing-masing anggota kelompok membaca bersama Defenisi Penelitian atau Metode Penelitian, Jenis-jenis metode Penelitian, Perbedaan Penelitian Kuantitatif dan Kualitatif lewat bahan ajar yang telah disiapkan oleh Dosen. Tugas mahasiswa pada LKM II adalah masing-masing anggota kelompok membaca bersama dan berdiskusi tentang Pengertian Rumusan masalah Penelitian, Karakteristik Rumusan masalah yang baik, Contoh Sumber-sumber masalah dan Tugas mahasiswa pada LKM III adalah masing-masing anggota kelompok membaca bersama dan berdiskusi tentang pengertian variabel dan jenis-jenis variabel dalam penelitian. Mahasiswa menuliskan hasil diskusi mereka pada lembar kerja mahasiswa. Secara umum, mahasiswa tidak mengalami kesulitan ketika diberikan tugas membaca dan menjawab tugas yang diberikan dosen. Mahasiswa dapat menemukan sendiri bersama anggota kelompoknya lewat membaca bahan ajar yang telah dibagikan, dosen hanya menjelaskan lebih lanjut ketika ada istilah-istilah yang masih baru dan tidak dipahami oleh mahasiswa. Gambar 2 menunjukkan hasil bacaan mahasiswa yang dituliskan pada lembar kerja.

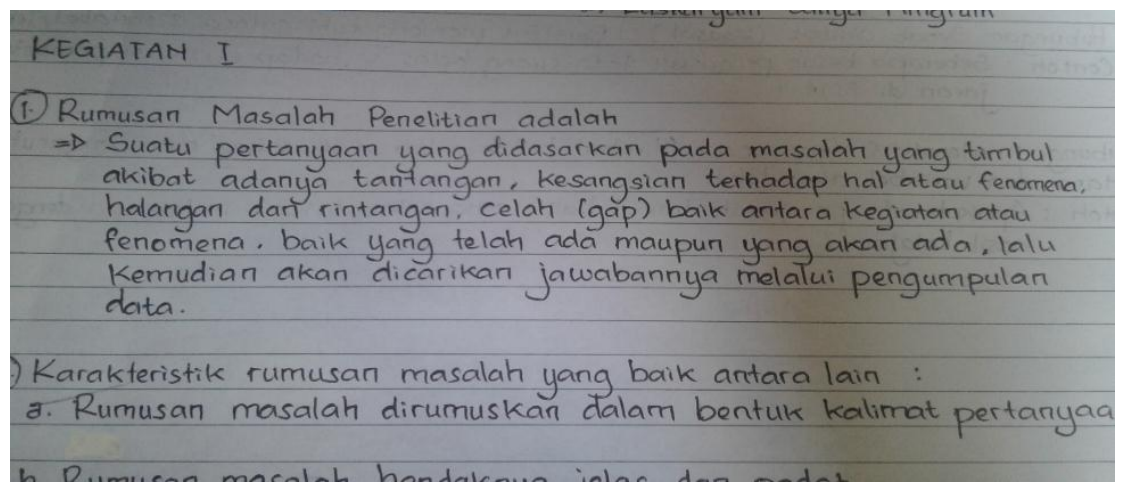

Gambar 2. Contoh Analisis Membaca Bersama Mahasiswa Topik Rumusan Masalah

Penggunaan Model Pembelajaran yang sesuai diperlukan dosen dalam pembelajaran metodologi penelitian, karena dapat mendorong tumbuhnya rasa senang mahasiswa terhadap pelajaran, menumbuhkan dan meningkatkan motivasi dalam mengerjakan tugas, memberikan kemudahan bagi mahasiswa mencapai hasil belajar yang lebih baik. Penggunaan model pembelajaran CIRC berbatuan website blogspot menyesuaikan dengan karakteristik mahasiswa dan materi pembelajaran. Pemilihan model 
pembelajaran yang tepat dosen dapat memilih atau menyesuaikan jenis pendekatan dan metode pembelajaran dengan karakteristik mahasiswa dan materi pelajaran yang disajikan (Aunurrahman, 2010)

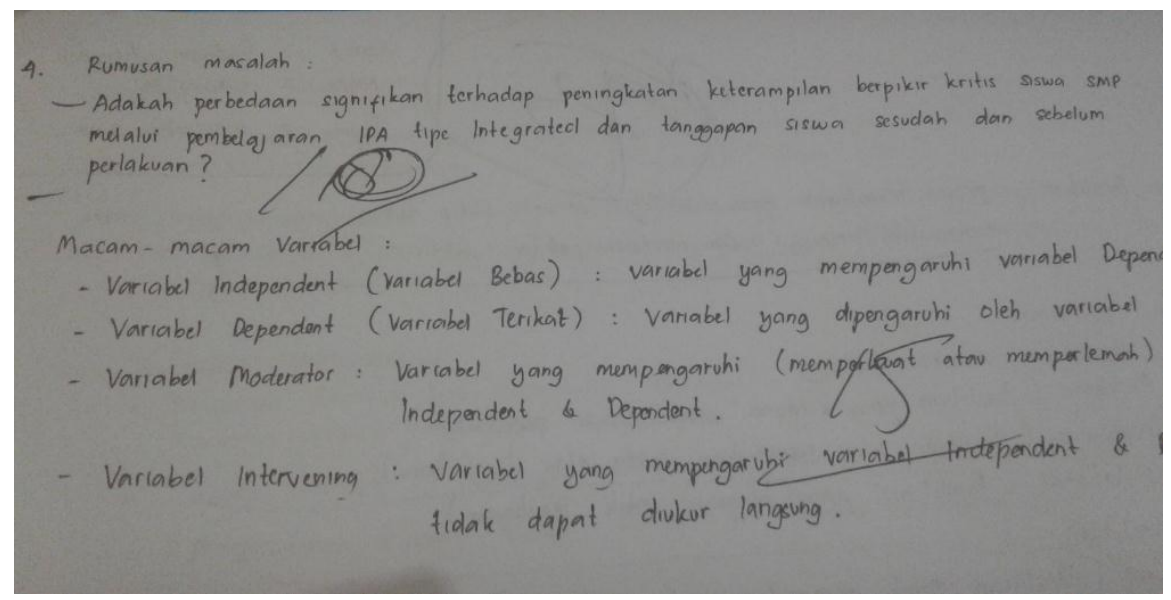

Gambar 3. Menunjukkan Contoh Pertanyaaan Hasil Belajar Ranah C3 Dan Salah Satu Jawaban Mahasiswa

Tujuan utama dari pembelajaran kooperatif CIRC adalah menggunakan tim-tim kooperatif untuk membantu mahasiswa mempelajari kemampuan bacaan yang dapat diaplikasikan secara luas (Slavin, 2008). Kelemahan pembelajaran tahap ini adalah dosen bersama mahasiswa perlu memberikan contoh-contoh penelitian yang telah dilakukan dalam pembelajaran fisika, sehingga mahasiswa lebih mampu pada tingkatan aspek kognitif menerapkan atau C3. Hal ini belum maksimal dapat diterapkan dalam pembelajaran, disebabkan keterbatasan waktu pertemuan. Pencapaian aspek kognitif menerapkan (C3) akan baik dicapai apabila mahasiswa banyak mengenal dan menganalisis artikel hasil penelitian yang beragam jenis. Beberapa mahasiswa belum mampu mengembangkan rumusan masalah pada suatu topik penelitian. Mahasiswa hanya mampu menyusun sebuah rumusan masalah.

Pertemuan pertama, mahasiswa dilatih menganalisis artikel jurnal secara bersama/kooperatif dari bahan ajar artikel Hasil Penelitian. Mahasiswa diberikan tugas mendiskusikan secara bersama dengan anggota kelompok yaitu tentang jenis penelitian, alternatif jenis penelitian, membuat contoh Judul Penelitian lain yang bersesuaian dengan jenis penelitian pada Jurnal, dan berlatih memberikan gagasan untuk memperluas atau memperkaya Jenis Penelitian dalam artikel. Pengembangan selanjutnya dilakukan diskusi online di blog dosen.

Berikut contoh jawaban mahasiswa pada diskusi online artikel jurnal berjudul hubungan keterampilan proses sains dengan penguasaan konsep serta kaitannya dengan gaya kognitif field dependent-field independent. 


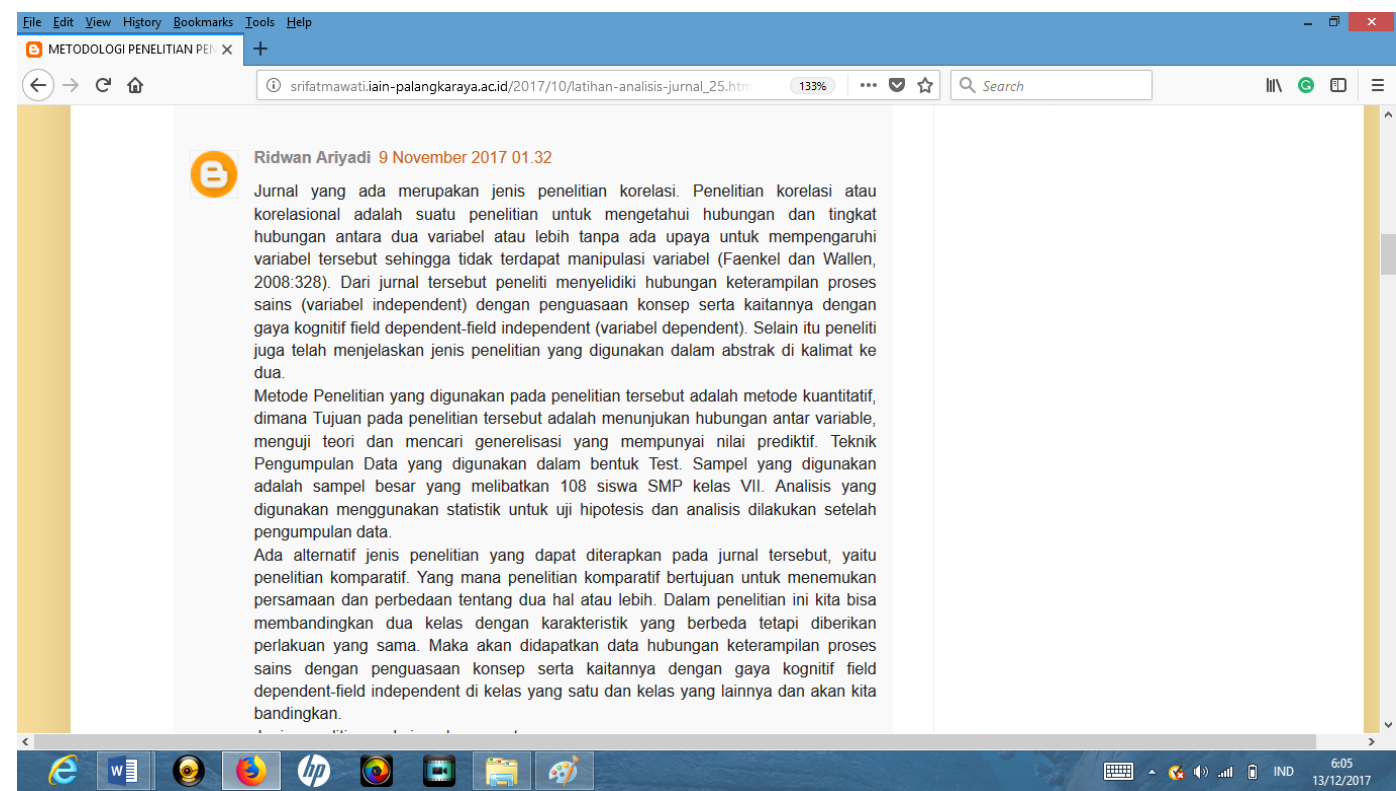

Gambar 4.Contoh Jawaban Mahasiswa pada diskusi online

Hasil penelitian oleh Nanda at al., (2013) mendukung hal ini yaitu model pembelajaran CIRC lebih banyak mengajak siswa berfikir baik secara individu untuk memprediksi jawabannya sendiri maupun dalam diskusi kelompok untuk berinteraksi secara mendalam dan mendorong siswa untuk berfikir kritis dalam memperoleh prediksi jawaban yang dianggap paling tepat. Pembelajaran CRIC berbantuan website blogspot cukup berhasil dalam menciptakan pembelajaran yang berpusat pada mahasiswa. Diskusi online memberikan kesempatan kepada mahasiswa untuk mengkaji lebih dalam kembali materi yang telah diperoleh pada saat tatap muka (Wijaya, 2012).

\section{SIMPULAN}

Berdasarkan hasil penelitian dan pembahasan dapat ditarik kesimpulan bahwa peningkatan hasil belajar mahasiswa setelah pembelajaran CIRC berbantuan website blogspot pada mata kuliah metodologi penelitian pendidikan fisika yaitu rata-rata $\mathrm{N}$-Gain adalah 0,62 termasuk dalam kategori sedang dan terdapat perbedaan yang signifikan nilai pretest dan postest pada penerapan penerapan model pembelajaran CIRC berbantuan website blogspot.

\section{DAFTAR PUSTAKA}

Aunurrahman. 2010. Belajar dan Pembelajaran, Bandung : Alfabeta, 2010

BM, S. M. 2015. penerapan pembelajaran fisika berbasis e-learning pada materi pokok fluida statis. Inovasi Pendidikan Fisika, 4(2). 
Hake, R. R. 1998. Interactive-engagement versus traditional methods: A six-thousandstudent survey of mechanics test data for introductory physics courses. American journal of Physics, 66(1), 64-74.

Hanum, N. S. 2013. Keefetifan E-Learning sebagai Media Pembelajaran (Studi Evaluasi Model Pembelajaran E-Learning SMK Telkom Sandhy Putra Purwokerto). Jurnal Pendidikan Vokasi, 3(1).

Huda, M. 2013. Model-Model Pengajaran dan Pembelajaran, Yogyakarta: Pustaka Pelajar.

Jenisa, K., \& Lubis, A. 2016. Penerapan Model Pembelajaran Cooperative Integrated Reading And Composition (CIRC) Untuk Meningkatkan Motivasi Dan Hasil Belajar Konstruksi Bangunan Siswa Kelas X TGB SMK Negeri 1 Lubuk Pakam. Educational Building, 2(1).

Kusmana, A. 2017. E-learning dalam Pembelajaran. Lentera Pendidikan: Jurnal IImu Tarbiyah dan Keguruan, 14(1), 35-51.

Madhu, G \& Jyoti, A. 2014. Cooperative Integrated Reading Composition (Circ): Impact On Reading Comprehension Achievement In English Among Seventh Graders. International Journal of Research in Humanities, Arts and Literature, 2(5), 37-46 .

Putranto, E. P. (2010). Penerapanmodel pembelajaran kooperatif tipe circ berbantuan moduluntuk meningkatkan keaktivan dan hasil belajar siswa kelas VIIIA MTS N 1 gemolong tahun ajaran 2009/2010 (Doctoral dissertation,Universitas Sebelas Maret).

Slavin, R.E. 2008. Cooperative Learning. Bandung: Nusa Media.

Wijaya, M. (2012). Pengembangan model pembelajaran e-learning berbasis web dengan prinsip e-Pedagogy dalam meningkatkan hasil belajar. Jurnal Pendidikan Penabur, 11(19), 20-27. 